\section{Series Editors: Anu Korhonen \\ Birgitta Svensson \\ Editorial Board: Chris Dixon}

\section{TITLES IN THIS SERIES}

Statistics, Public Debate and the State, 1800-1945: A Social, Political and Intellectual History of Numbers

Jean-Guy Prévost and Jean-Pierre Beaud

\section{ForthCOMING Titles}

A Cultural History of the Radical Sixties in the San Francisco Bay Area Anthony Ashbolt

Breast Cancer in the Eighteenth Century Marjo Kaartinen

Crime and the Fascist State, 1850-1940 Tiago Pires Marques
A HISTORY OF EMOTIONS, 1200-1800

EDITED BY

Jonas Liliequist

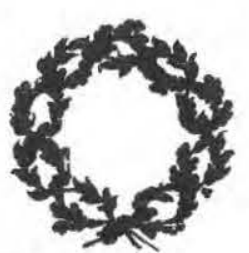

PICKERING \& CHATTO 2012 
Published by Pickering \& Chatto (Publishers) Limited

21 Bloomsbury Way, London WCIA $2 T H$

2252 Ridge Road, Brookfield, Vermont 05036-9704, USA

$$
\text { www.pickeringchatto.com }
$$

All rights reserved.

No part of this publication may be reproduced, stored in a retrieval system, or transmitted in any form or by any means,

electronic, mechanical, photocopying, recording, or otherwise without prior permission of the publisher.

(c) Pickering \& Chatto (Publishers) Ltd 2012

$$
\text { (C) Jonas Liliequist } 2012
$$

To the best of the Publisher's knowledge every effort has been made to contact relevant copyright holders and to clear any relevant copyright issues.

Any omissions that come to their attention will be remedied in future editions.

BRITISH LIBRARY CATALOGUING IN PUBLICATION DATA

A history of emotions, 1200-1800. - (Studies for the International Society for Cultural History)

1. Emotions - History. 2. Emotions - Religious aspects. 3. Affect (Psychology)

4. Sensitivity (Personality trait)

I. Series II. Liliequist, Jonas.

$152.4^{\circ} 09-\mathrm{dc} 23$

ISBN-13: 9781848933569

e: 9781781440049

This publication is printed on acid-free paper that conforms to the American National Standard for the Permanence of Paper for Printed Library Materials.

Typeset by Pickering \& Chatto (Publishers) Limited

Printed and bound in the United Kingdom by the MPG Books Group

\section{CONTENTS}

List of Contributors

List of Figures

Introduction - Jonas Liliequist

I. Theoretical Issues

1 Theories of Change in the History of Emotions - Barbara H. Rosenwein

2 Ottoman Love: Preface to a Theory of Emotional Ecology - Walter Andrews

II. Emotional Repertoires

3 Preachers, Saints, and Sinners: Emotional Repertoires in High Medieval Religious Role Models - Christina Lutter

4 Theology and Interiority: Emotions as Evidence of the Working of Grace in Elizabethan and Stuart Conversion Narratives - Paola Baseotto

5 'Finer' Feelings: Sociability, Sensibility and the Emotions of Gens de Lettres in Eighteenth-Century France - Anne C. Vila

III. Music and Art

6 Music as Wonder and Delight: Construction of Gender in Early Modern Opera through Musical Representation and Arousal of Emotions - Johanna Ethnersson Pontara

7 Politesse and Sprezzatura: The History of Emotions in the Art of Antoine Watteau - Pamela W. Whedon

IV. Gender, Sexuality and the Body

8 Emotions and Gender: The Case of Anger in Early Modern English Revenge Tragedies - Kristine Steenbergh

9 Beauty, Masculinity and Love Between Men: Configuring Emotions with Michael Drayton's Peirs Gaveston - Anu Korbonen

10 'Pray, Dr, is there Reason to Fear a Cancer?' Fear of Breast Cancer in Early Modern Britain - Marjo Kaartinen 
V. Uses of Emotions

11 The Litcle Girl who could not Stop Crying: The Use of Emotions as Signifiers of True Conversion in Eighteenth-Century Greenland - Allan Sortkier

12 The Political Rhetoric of Tears in Early Modern Sweden

- Jonas Lilieguist

Notes

Index

\section{LIST OF CONTRIBUTORS}

Walter Andrews received his $\mathrm{PhD}$ from the University of Michigan Near East Languages and Literature Department in 1970. He taught Turkish and Ottoman literature in the Department of Near Eastern Languages and Civilization at the University of Washington from 1968 until his retirement to a research professorship, which he still holds. He has published several books, translations, articles and edited works on Ottoman literature, modern Turkish literature, and literary theory in English and Turkish. Among his books are Poetry's Voice Society's Song (University of Washington Press, 1985), revised and translated into Turkish as Siirin Sesi Toplumun Sarkts, Ottoman Lyric Poetry: An Anthology (with Mehmet Kalpaklı and Najaat Black) with an expanded reprint from the University of Washington Press and most recently The Age of Beloveds: Love and the Beloved in Early-Modern Ottoman and European Culture and Society (with Mehmet Kalpakll, Duke University Press, 2005). His translations of modern Turkish poetry include selected poems by Hilmi Yavuz (Seasons of the Word, Syracuse University Press, 2007) and by Araol Behramoğlu (I've Learned Some Things, University of Texas CMES, 2008). He is also co-director of the Ottoman Texts Archive Project [OTAP], a web-based resource developing tools and methods for the archiving and analysis of Ottoman texts. In 2008, he was awarded The Turkish Republic Order of Merit Medal by vote of the Turkish Parliament 'for valuable studies and contributions to the Turkish Republic'.

Paola Baseotto holds a PhD from the University of Reading (UK) and teaches English culture and history at Insubria University, Como, Italy. Her research interests centre mainly on the works of Edmund Spenser and on the theological, legal and medical treatises of the Renaissance period. She is the author of articles for academic journals and of the volumes Fighting for God, Queen and Country: Spenser and the Morality of Violence (2004) and 'Disdeining Life, Desiring Leaue to Die': Spenser and the Psychology of Despair (2008). She has presented papers at international conferences throughout Europe and has been invited to teach seminars at Loyola University (Chicago), Princeton University and Hunter College (City University of New York). 


\title{
3 PREACHERS, SAINTS AND SINNERS: EMOTIONAL REPERTOIRES IN HIGH MEDIEVAL RELIGIOUS ROLE MODELS
}

\author{
Christina Lutter
}

O Lord, born of the virgin ... smiling at his mother, through this smile allow me, beg, to participate in your perpetual happinesss ... O Lord, sucking at your mother's breast ... reclining on your mother's lap ... O Lord, hardly able to speak in a babbling voice ... circling the mother as small children do ... kissing your mother's sweet lips ... and embracing the beloved mother's neck ...

This stunning fragment of a much longer prayer in a twelfth century prayerbook, probably from the female community at Nonnberg in the bishopric of Salzburg, may rightly, or so it seems, be labelled 'emotional', even if we would perhaps not expect this kind of expression in a monastic context. But what directs our expectations when reading such a text? What indicates that we are dealing with 'emotions' here? And if we are, how can we be sure that the medieval contemporaries' understanding of 'emotions' and their modes of expression are accessible to our modern approaches and comparable to our notions? In this chapter I want to approach these questions via a close reading of monastic source material of the twelfth and early thirteenth centuries. ${ }^{2}$

Current debates on 'emotions' in the humanities, cultural studies and sciences alike are characterized by a range of different attempts to enumerate, classify and define what 'emotions' are; so far, though, they seem to defy a systematic definition. ${ }^{3}$ The situation gets even more complicated if we take into account that the usage of the terms 'emotions', 'feelings' or 'sentiments' is anything but congruent in different modern languages, each having its own distinct linguistic history, and that the same holds true for our source material, as there are a number of attempts at defining and classifying emotions in historical texts. ${ }^{4}$ Both in ancient Latin and in medieval texts one will find various descriptions and definitions of emotions. The first systematic Latin list of 'emotion words' - non-exhaustive enumerations of terms articulating feelings like joy, grievance, anger, hate, envy, etc. - was given by Cicero. ${ }^{5}$ In the Latin Middle Ages similar lists were compiled by the Church Fathers. They adopted the majority of the ancient Latin terms, 
yet their meaning changed according to Christian imaginaries and notions of morality. As in ancient texts we also encounter collective terms, such as affectus or affectiones, passiones or perturbationes in medieval sources. Far less frequent are attempts at definition, as by Augustine who defines affectiones nostrae as motus animorum and strives to delineate the origin of emotions in order to explain what they are: 'Among the philosophers there are two views of these motions of the soul [animi motibus], which the Greeks call pathé but which some of us, like Cicero, call perturbationes and which others call affectiones or affectus, and still others, like [Apuleius], call passiones, which is closer to the Greek'.6

Whatever emotions might be or have been thought to be, though, cultural historians generally agree that they can never be grasped directly, but only be traced via language and other representations such as pictures or material culture. 'None of these things are the emotion; they are symptoms that must be interpreted - both by the person feeling them and by observers', as Barbara Rosenwein puts it. That becomes most evident in a historical perspective, as our sources get scarcer the farther back they date. To complicate things even further, each audience, present or past, each reading of a text, a picture or any other object produces new representations, i.e. meanings that in turn modify the objects of interest. These ongoing processes of 'meaning-production', the models used to form and shape them, i.e. how emotions are conceptualized and come into existence, are themselves part of what 'emotions' are. ${ }^{8}$

Nonetheless, this 'how' is exactly what one can search the source material for. I am interested in the ways people expressed sensations and emotions that were only indirectly accessible to them, let alone to us, and in the kinds of effects they produced. What were the shared expectations directing and regulating perceptions and thus influencing how people experienced a certain event or a specific sensation? How were perceptions constructed along certain patterns providing the framework for sensual experiences and the sensation of emotions? ${ }^{9}$ What kinds of textual and rhetorical, but also figurative and material strategies and rechniques were deployed? I am interested in patterns and models of spiritual notions and sensations present in historical texts and pictures, in hints at their emotional expressions in the practices described or depicted therein, as well as in the symbolic knowledge that people could draw on in articulating them in specific social contexts.

In medieval theological texts, starting with the Desert Fathers, emotions are increasingly given a distinct moral quality and corresponding evaluation. At that time their allocation as virtues or vices begins to play an important role, as sometimes also does the demarcation of affects from virtues, with a tendency to identify the former with the notion of sin, as in the concept of the Seven Deadly Sins. ${ }^{10}$ These notions were linked to considerations about a morally good life oriented towards redemption, and can be found in catalogues of virtues and other 'tools' for religious orientation and instruction. They provide indications for what was considered an exemplary life, and how its standards were supposed to be put into practice. An important model that was continuously used and adapted in religious texts and plays all through the Middle Ages was the Psychomachia, the battle of virtues against vices, by the Latin poet Prudentius ( $d$. after 405). ${ }^{11}$ Famous examples of its use and reception in the twelfth century are the Ordo virtutum by Hildegard of Bingen, an early form of liturgical drama drawing on the imagery of the Psychomachia, and the Hortus deliciarium, a spiritual guide for the members of the female community of the Alsacian convent at Hohenburg, composed by their abbess Herrad. ${ }^{13}$

Barbara Rosenwein points out that until the twelfth or thirteenth centuries the Latin Middle Ages did not see attempts, comparable to those of Aristotle or Cicero, to treat emotions systematically, as part of a theory of the soul. Just as important I consider her observation that contemporary analyses of medieval 'emotion words' need to look beyond the canonized classical texts to include the richness of the tradition that informs us about the reception of these notions and the imagery linked to them. ${ }^{13}$ Especially in times of religious reform movements the differentiation of religious ways of life involved a significant increase in the literary and pictorial tradition, mostly found in monasteries as the centres of contemporary production of knowledge. In didactic and edifying literature for the production of 'inward' images for spiritual exercises one finds complex compositions of text and pictures, meant to assist in the appropriation of contents. Since the late twelfth - and especially in the thirteenth - century, illuminated manuscripts and prayerbooks played an important role as visualizing tools for prayer. $^{14}$

This chapter focuses on cultural repertoires of emotions represented in examples (exempla), as used in saints' lives and miracle stories (miracula), in sermons, prayers and 'mirror'-literature (specula) from twelfth- and thirteenthcentury monastic communities. These texts provide fascinating insights into representations of religious beliefs, and their spiritual and social contexts. They address different audiences, but all are embedded in monastic education, pastoral practice and daily liturgical routine. They thus give insight not only into contemporary normative ideals and theological theory, but also into what we might conceive of as everyday lived practice and the adaptation of extant cultural and emotional repertoires as modes and options that simultaneously direct and limit, but also enable people's actions, beliefs and feelings. ${ }^{15}$

One of the best known contemporary collections of miracle stories, the Dialogus miraculorum, written by the Cistercian monk Caesarius of Heisterbach around 1220 , gives a comprehensive insight into how contemporaries conceived of and made use of exempla, as the author on several occasions defines the functions of examples. In this didactic conversation between an older monk and a 
young novice in the tradition of medieval monastic dialogue, the former on one occasion claims that he wants to instruct the latter 'more by means of examples than by words' (de hoc magis te instruam exemplis quam verbis), just as elsewhere the pupil asks to be taught magis exemplis quam sententiis. ${ }^{16}$

Caesarius himself explains in his prologue to the Dialogus miraculorum that his pupils urged him to also conserve in writing the miraculous events he had orally presented to them. First he was hesitant, he says, using the usual topoi of humility and also mentioning his fear of enviers and critics, but then he submitted to the authority of his superiors; he chose the form of the dialogue not least to conceal his authorship behind the conversation and thus be less vulnerable to critics. ${ }^{17}$ Aided by the dialogic structure of the text, Caesarius moreover deliberately emotionalizes by means of dramatic narrations. ${ }^{18}$

Caesarius draws his exempla from the communicative practice of the Cistercian order, within which forms of oral and written tradition related to each other in complex ways. Two thirds of about 750 exempla organized in twelve distinctiones are from oral sources for which he mostly gives date, place and witnesses. Most of them were told by fellow monks and abbots whom he met at the regular meetings of the Cistercian general chapter and in the course of visitations; others were told by nuns, clerics and laypeople of both genders. Caesarius explicitly stresses that many stories happened in the world beyond the walls of the monastery. ${ }^{19}$ While Cistercian pastoral care programmatically focused little on lay people, and we may thus assume that the main audiences addressed by Caesarius were to be found among the members of the order, still the boundaries between pastoral care inside and outside the monastery became less distinct from the thirteenth century onwards. Many thematic motives figuring both in Caesarius's Dialogus miraculorum and in his sermons found their way into the contemporary collections of exempla which in turn served as resources for pastoral preaching to the laity. ${ }^{20}$

At any rate, many members had only entered the Cistercian order as adults, and pastoral care for conversi represented a connective element between different groups of audiences. Thus, the social and cultural background of these monks and conversi is that of the world outside the monastery and of their - often noble - ancestry. Therefore, many examples deal with monks, clerics or conversi who behave like knights. ${ }^{21}$ For example, a story is told about several monks and, above all, conversi who fell asleep while their abbot was preaching, but they immediately woke up when he started to tell the story of king Artus. Many stories feature members of the order fussing about their outward appearance, their shoes, clothes and horses as symbols of status, and about their corporeal wellbeing, which might suffer in the monastic environment. ${ }^{22}$

Thus, Caesarius explicitly draws not only on Christian doctrine and exegetical explanations, but also on lived experience. In his understanding, exempla are events worth remembering for their exemplary, miraculous and edifying content. By virtue of their relatedness to personal encounters and experiences and specific social environments they are intended to be comprehensible directly and sensually, thus suited to serve as models and illustrations. ${ }^{23}$ Therefore Caesarius draws on textual models for this type of instruction, most prominently Gregory the Great's Dialogues, and combines them with oral narrative traditions. ${ }^{2+}$ Thus he links the written to oral tradition, actualizing biblical assertions, above all from the history of salvation, in relation to his own time and to concrete contexts familiar to his audience. These memorable stories told over and over again in the course of monastic life were thus incorporated into the repertoire of instruction, exegesis and theological discourse.25

Quite the same - though without the dialogical framework of a didactic discussion, without identification of literal and oral sources and theoretical considerations on the nature of miracles - holds true of the various collections of miracle stories proliferating at sites of pilgrimage and monasteries throughout Europe since the second half of the eleventh, and especially in the twelfth and the thirteenth centuries, not least due to the increasing practice of preaching to the laity. ${ }^{26}$

Res mira horrendaque are contemporary terms describing wonderful and at the same time horrible events people experienced through the acts of saints, events that were meant to edify, astound and terrify them, as well as serve as exempla for them. ${ }^{27}$ Like other hagiographical texts, but also prayerbooks and sermons drawing on examples, miracle collections thus served as devices for edification and spiritual instruction both for people in monastic communities and, since the thirteenth century, also for a lay audience. Medieval collections of miracles could take different forms: Some compilations are limited to specific saints or local traditions. Other collections contain stories of various temporal and spatial origins and offer a range of interrelated references. Often common narratives are bound together with single stories that refer to local traditions pertaining only to specific communities. ${ }^{28}$ The latter, mostly added at the end of the compilations, are especially interesting as they, just like the stories of Caesarius, provide us with various hints at specific social and cultural contexts of the respective communities and the people belonging to them, reaching far beyond the well-known patterns of topical models of sin, conversion and redemption. Relating and comparing these stories to each other thus opens perspectives on common spiritual models, emotional repertoires and possible uses of and variations on them.

A collection of Marian miracles from the reform monastery of Admont in Styria (today's Austria) that I now want to consider more closely contains partly adapted exempla taken from the writings of various early to high-medieval authors including some of only regional importance. ${ }^{29}$ Admont was a Benedic- 
tine reform monastery consisting of a men's and, from the twelfth century on, a women's convent and highly involved in the debates about the political and spiritual reforms of the time. In these debates - at least that is what the abundant Admontian source material suggests - the monastery's sanctimoniales had no lesser part than their fellow monks, which is consistent with the reform ideal of women and men sharing a communal life in the spirit of the vita apostolica. This way of life presupposed at least some contact between the two sexes constituting, however, a latent danger for one of the basic elements of monastic life, the virtue of chastity. ${ }^{30}$ This intrinsic conflict, just like other key issues of the reform, was the subject of heated debates, many of which were reflected in writing. Religious differentiation thus led to a significant rise in literary production and tradition. ${ }^{31}$ Hence many of Admont's manuscripts contain texts and corresponding illuminations dealing with the discussion and the exercise of a spiritual way of life, thereby both pointing at contemporary concepts of piety, and representing their practical implementation. ${ }^{32}$

Codex Admont 638, from the second half of the twelfth century, contains a collection found in many monastic libraries of different congregations all over the German-speaking world. It consists of forty-two stories of varied provenance that in the course of copying were, in some locales, completed by further exempla. ${ }^{33}$ In the Admont manuscript there are four additional stories: The well-known early medieval legend of Theophilus also found in many highmedieval collections, followed by three additional stories apparently exclusive to this manuscript. ${ }^{34}$

All these stories focus on the miraculous deeds of the Mother of God simultaneously acting as redemptrix, advocate and role model. Most of the texts are rather short and simple in style, yet very concise and seem, like Caesarius's exempla, close to what might be considered everyday life. The scenes, though, are set at 'typical' monasteries whose specific locations therefore are rarely identified; the actors are nameless clerics and monks, nuns and abbesses, occasionally also laypersons, men and women, peasants, travellers and pilgrims, sick people and thieves. The cast in Caesarius of Heisterbach's Dialogus miraculorum is likewise heterogenous, though both in his monastic dialogue and in the main body of Admont's collection the focus is clearly on the males, mostly monks and clerics. However, it should be noted that the three additional miracula in the Admontian manuscripts feature almost exclusively women with the exception of one cleric. ${ }^{35}$ The stories describe the manifold forms of temptation and sin people were imagined to be exposed to, both within the monastery and outside its walls, as well as remorse and salvation with the help of the Holy virgin. These stories thus offer a view of the 'downside' of what edifying texts and sermons, saints' lives and catalogues of virtues present as an exemplary way of life. They point to the contradictions and conflicts people encountered in striving for the imitation of such a lifestyle, and to their attempts to find solutions for, or ways to cope with them. Moreover, it is particularly these conflicts and ambiguities that provide interesting material in which to look for emotional repertoires and interrogate them for the options of their uses and possible modifications.

'Once upon a time there was a certain nun in a particular convent ... who was loved by everyone, more than any other sister', begins one of the stories. 'For more than all the others she was zealous in fasting, keeping vigils, and sighing, and in as many of the other virtues as possible, pleasing the Lord and His Mother.' Thus she lived in obedience until the devil, feeling despised by such great virtue, decided to ensnare her and led her to disdain the commandments of the Lord and lose the virginity that she had preserved in spirit and body.36

How this happened the story does not tell. Neither does it give any information about the further life of the now fallen nun, but only continues after her death:

Soon the recently deceased, bitterly lamenting and regretting her crime (perhorruit ... peninuit), appears in front of the abbess of the monastery, who is not afraid, bur immediately questions her about the punishments for her sins. Indeed, the deceased explains that she was suffering and 'severely burning' for relinquishing her life as 'a virgin pure and promised to the Lord. ${ }^{37}$

Yet the Virgin Mary, she reports, had appeared to her, and thus the following dialogue evolved:

Bursting into tears she laments her suffering and implores Mary to deliver her from these pains, not without pointing out her love and devotion during her lifetime. ${ }^{38}$ Now the Mother of God expresses her anger against the nun: As a virgin promised and consecrated to Christ she had deserted him and had gotten involved with the devil: '... Who disdains my son cannot revere me!' Yet. Mary continues, her good deeds are speaking for the sinner, most notably the love and devotion shown towards her. For that reason the nun would not be repudiated, but saved. ${ }^{39}$

This example - and in the context of this essay I can only provide a methodologi$\mathrm{cal}$ outline for a more comprehensive textual analysis - simultaneously shows models, functions and practices of emotions in such texts: as in contemporary scholarly treatises, emotions here are closely intertwined with moral concepts. In the beginning, the exemplary ascetic practice of the anonymous nun is emphasized as the very embodiment of virtue. Let us have a look at the words employed here: The nun pleases (placens) the Mother of God and her son, is loved by everyone (amabatur), for she fasts, keeps vigils and sighs like no other. Grouped around the 'emotion words' placere and amare we find words originating in ascetic practice (ieiuniis studebat vigiliis), that in turn feature emotional articulations - sighing, and subsequently bursting into tears and lamenting. ${ }^{40}$ The opposite of the virtue enacted is vice, impersonated by the devil. He represents 
envy (qui semper est invidus), feels repulsed (repulsus) and taunted (despectus) by the virtuous nun till he succeeds in inducing her to forsake her chastity.

As mentioned before, the story does not give us any details about this. Nevertheless the irreversibility of her deed is staged in a most dramatic fashion by the sudden change of scene from the exemplary life of the nun to her suffering after death. Additional modes of this enactment are the dialogic form, especially between the Virgin Mary and the sinner, and the metaphors chosen, particularly the image of the loving attachment to the heavenly bridegroom, whom the $\sin$ ner deserts and thus wounds. By doing so she drives the Mother of God, i.e. the bridegroom, to utmost rage (maximam iracundiam).

The wound the sinner inflicted on Christ is contrasted with the sinner's love and reverence towards Mary both during her lifetime and after her death. Even more than in the beginning of the story, the frequency, regularity and intensity of her devotion are emphasized and related to her tears and laments:

Wecpingly the sinner calls out to the Mother of God (exclamavi flens), whom she reminds of her love and imploration (amavi et imploravi), and finally the Virgin Mary promises to the bitterly weeping woman (mibi a mare flenti) salvation because of the love she daily used to practice (quia me cottidie salutabas, dulcissime serviebas. bonorabas, extollebaser amabas, ... salvaberis).

Contrition and humility, as requirements for salvation, are both among the most important virtues and the central motives of Christian thought and affective practice. In his consideration of the subject, Caesarius of Heisterbach explicitly links 'inner' and 'outer' sensations, thus giving an idea of his conceptual understanding of the working of emotions: The inner contrition (contritio) is located in the bitterness of the heart; its outer effects are visible from the body's affliction. He gives a number of examples that relate the movements of the heart (motus cordis) with specific corporeal signs (signa). ${ }^{41}$ This is also made clear by their dramatic enactment in the Admontian miracula: The vocabulary of perception and sensation is most striking, especially adverbs and adjectives, the latter often set in superlatives, and the verbs that in accordance with the mentioned concepts of ancient and medieval authors express '(e)motions' in the sense of physical movements as well as of motus animi. Moreover the crying, lamenting and prostrating oneself represented here, coupled with the devotion to the Mother of God practised every day, is exemplary for the ritual sequence of prayer, penance and atonement. The story thus also seems to establish a link to regular liturgical practice, which corresponds to the fact that exempla from collections like this would principally be used both in monastic liturgy and as material for sermons, as we explicitly know in the case of Caesarius of Heisterbach and the relationship berween the exempla used in his Dialogus miraculorum and his sermons. ${ }^{42}$

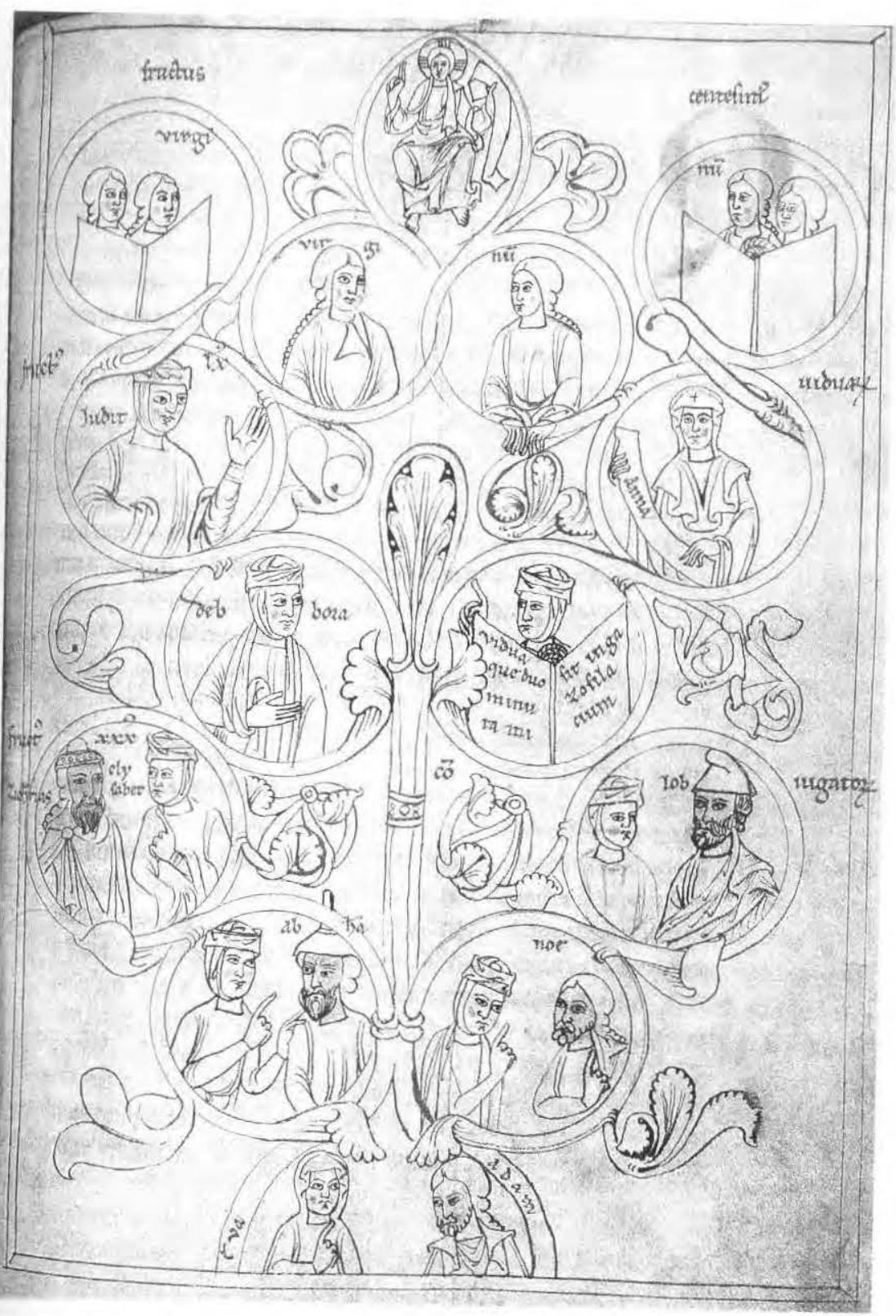

Figure 3.1: Speculum virginum, 'The Fruit of the Orders': Zwettl Abbey (O.C.), Chapter Library, MS 180, fol. 76r.

Regarding style, both narrative and performative strategies are deployed, especially through forms of dialogical representation, in this case between the Mother of 
God and the sinner and between the latter and the abbess of the monastery. These enactments illustrate the significance of imagining figures mediating between the divine and the human, between the sacred and the secular. In this, saints, but also the devil and demons, play an extremely important role as translators. Likewise, the explicitly emotional behaviour of an exceedingly angry Mother of God (me quoque ad maximam iracundiam commovisti) also serves this performative and thus 'translating' function. ${ }^{43}$ Just like specula - instructive devices that present an exemplary life meeting the religious norms - these narratives thus function as tools for an exemplary, yet comprehensive learning by sensually and not least, emotionally 'in-corporating' their contents. This kind of knowledge was understood to serve a deeper spiritual understanding, thereby being a tool for redemption.

This is the case with, for example, the Speculum virginum, where the Virgin Mary is called the mirror of holy virginity (speculum sanctae virginitatis) - just as this didactic manuscript itself is imagined as a mirror of and for the virgins. ${ }^{44}$ The manuscript was composed in the first half of the twelfth century by an anonymous author from the Middle Rhine, supposedly as a pastoral manual. As the Dialogus miraculorum its form is a dialogue, this time between the (fictitious) pupil Theodora and her (also fictitious) teacher Peregrinus, and it depicts traditional Christian concepts of order dating back to patrology (cf. Figure 3.1). According to these, the divine world order was envisaged as organized along ordines. In addition to the functional tripartition into monks, clerics and laymen dating back to Augustine, the basic social ordinal scheme was that of the moral ordines: virgins, widows and married ones. This moral economy applied to both sexes. It rested upon the principle of chastity as the criterion by which everyone would be judged and classified in this, but particularily in the next, world. Accordingly, male and female 'virgins' took the highest rank within this 'order of chastity.45 The virgins by this moral order simultaneously were 'brides of Christ'. The well-known Latin Speculum virginum links the moral-emotional figures of virtues and vices to this imagery.

Similarly, the St Trudperter Hohelied, representing one of the first known exegeses of the Song of Songs in the German vernacular, was designed to be an affective 'mirror' for the brides of Christ. It was probably composed some decades later perhaps in Admont or at least in the same geographical region, and designed to be a way to teach the loving understanding of God (ein lêre der minneclichen gotes erkennüsse). ${ }^{46}$ While traditionally the brides' most important virtues were thought to be humility and chastity, the idea of 'brides of Christ' itself points to further aspects of affective identification: Due to their ordo and their virginal way of life they were considered to be pledged to the divine bridegroom. This was a highly emotionalized model taken up most prominently in the theological discussions of the Song of Songs flourishing at this very time, but apparently also in more 'popular' texts as represented by the Admont miracle, when Mary as the bridegroom's mother bitterly laments the breach of the pledge by the fallen bride. ${ }^{47}$

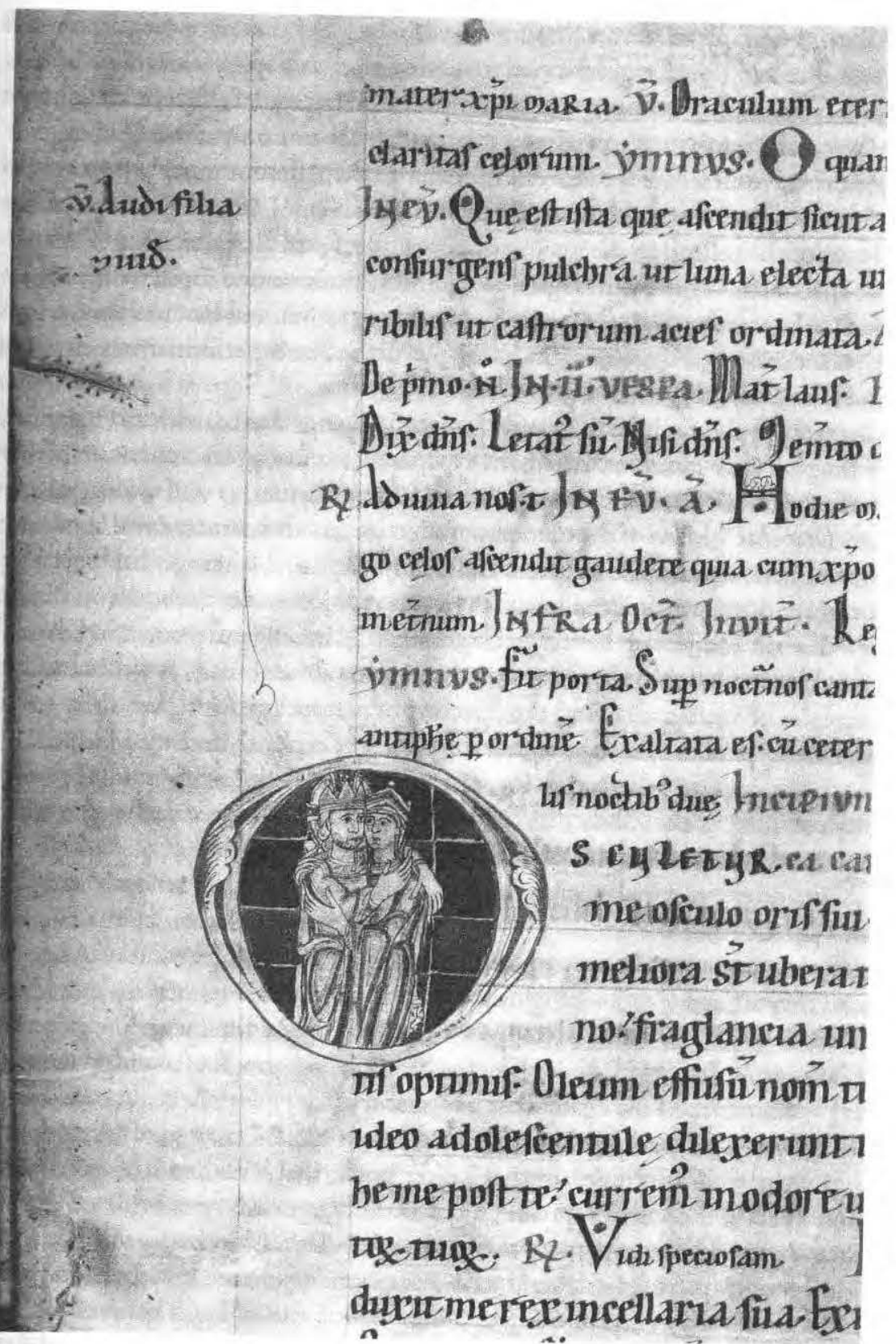

Figure 3.2: Matutinale, 'The Heavenly Bridegroom and His Bride': Admont Abbey (O.S.B.), Chapter Library, MS 18, fol. 164v. 
All these examples draw on emotional vocabulary and corresponding rhetorical techniques and thus suggest a narrative invitation to a spiritual imitatio of the bridal relationship between Christ and the believing soul, for which the Virgin Mary at the same time served as a role model, Yet not only narrative, but also performative elements are at work in them. In the Admont miracle the change of scenes brings about an important dramatic moment. In one of the subsequent stories of the collection the manuscript even offers explicit indications of its scenic enactment. Again, with regard to the monastic lectio one could well imagine that such texts would be performed with assigned roles, and that in doing so the events represented therein might have been all the better performatively enacted and affectively adopted. ${ }^{48}$

Here we also find a link to early forms of religious drama, such as Hildegard of Bingen's Ordo virtutum, a dramatic experiment featuring personifications of the human soul, Anima, her fellow Souls, and sixteen Virtues, as well as their adversary Diabolus. ${ }^{49}$ Many of the elements of affective enactment mentioned above are present here: the dialogic structure and highly allegorical language that especially foregrounds the personifications of the virtues and vices and of the brides of Christ, as well as the imagery of the militia Christi, enacted by religious women, laced with numerous emotion words, exclamations and gestural vocabulary, as well as textual strategies of visualization and the directing of perception. Moreover, there are a number of phrases that suggest that the piece was explicitly intended for performance, as does its preservation together with complete music. According to the play's editor it is even likely that Hildegard composed the piece deliberately with "her twenty available women performers in mind," ${ }^{0}$

The extent to which such representations would be taken seriously and put into practice and the conflicts this could bring about is shown by the famous epistolary argument between Hildegard of Bingen and Tenxwind of Andernach. They argued whether religious women in Hildegard's monastery should, as brides of Christ, be allowed to appear beautifully dressed and with loose hair, or if this - thus Tenxwind's criticism, she herself being abbess of a reform monastery - contravened the egalitarian reformatory principles of the vita apostolica and the pauperes Christi.5.

By the same token, in another prayer book, the Matutinale of Admont's nuns (1180), the visual representation of the Virgin Mary as bride of Christ plays a particularly important role. Here the relationship between bride and bridegroom is pictured in several ways. For example, consistent with the text, the initial to the lesson on the Song of Songs depicts the embrace between Christ the bridegroom and the Virgin Mary as his bride in an exceedingly sensual way (cf. Figure 3.2). Another striking feature of this miniature is that Mary's dress shows similarities to representations of nuns in other Admontian manuscripts, as other miniatures in this codex show resemblences to contemporary courtly fashion. The depiction of the Virgin Mary not only as Mother of God but also as queenly maiden, identifiable by dress, jewellery and loose hair, indicates the importance of suitable representations for high-born women. ${ }^{52}$

Speaking of the role model of the brides of Christ, there are also striking similarities between the terminology of love and friendship in spiritual texts, especially related to the Song of Songs, and those found in metaphors of friendship and courtly love, hinting at fluent transitions between the imageries inside and outside the monastery. Thus emotional communities, to draw on Barbara Rosenwein's concept, are not necessarily congruent with functionally defined communities, just as the social life of people, especially in times of reform, was not confined to one sphere of living..$^{53}$ We know from letters, but above all from charters that document donations made on the occasion of conversions to many reformed monasteries, that members of the convent entered into the community only after reaching middle age or near the end of their lives, and that sometimes they also considered leaving it, as did the sinner in another narration in Admont's miracle collection ${ }^{54}$ Children and juveniles were committed to the monastery by their parents or relatives, but others only arrived as adults, some with, others without their children after being widowed. Some disposed of their possessions themselves, others decided in close communion with the other members of their family; for others still, third persons appear to have taken the responsibility.

In a moving letter from a letter collection preserved in Admont, which in its use of emotional vocabulary is comparable to the quoted prayer from Nonnberg, an anonymous woman complains before the Archbishop of Salzburg that she had, apparently on his advice, not only left all her friends and relatives when entering the monastery, but also had given away her newborn child right after giving birth within the monastery. Now, she claims, would he arrange for the child to be raised by her anyway and, one might add, despite the monastic enclosure, lest her anguish might even force her to leave the monastery? ${ }^{355}$ The exemplary nun in the initially presented example from Nonnberg, whom we know as little about as we do about the nameless scribe from Admont, surely had seen mothers and babies, either outside the monastery or even within its enclosure. Although our sources only allow speculations about the concrete circumstances of their individual stories, still the model prayer of the exemplary woman at Nonnberg points to possibilities for a better integration of mundane into monastic experience, apparently not open to the nun at Admont. At any rate, the transformation of apparently worldly approaches into positive spiritual imagery seems to suggest this.

Textual witnesses from monasteries since late antiquity give evidence that the loss of beloved ones was felt by those entering a community. ${ }^{56}$ Assertions of the spiritual advantages and the will to an exemplary way of life as we find them in specula, vitae and sermons contrast fears of being forgotten and the attempts 
to contact people outside the monastery, be it by requests for visits or by at least the realization of personal relationships through written correspondence. Legends like that of an 'apostate woman' and her lovers, a cleric in love with a nun from a nearby convent, or else of 'the pregnant abbess', which are all part of Admont's miracle collection, correspond to other references to 'moral deficiencies' - for example, the entry in Admont's annals regarding pregnant nuns at St Georgen on Längsee in Carinthia, written down at the beginning of the twelfth century. ${ }^{57}$ About 100 years later Caesarius of Heisterbach reports comparable difficulties concerning monks and nuns willing to leave their communities, and gives numerous examples of the rising numbers of such fugitivi, as well as dedicating a whole book of his dialogue to the diverse forms of temptation and their consequences. ${ }^{58}$

The links between monastic communities and the world outside are further stressed by the fact that the practice of teaching and learning by imitation of exemplary role models and habitual appropriation of certain ways of life was by no means specific to the monastic field. Also in the courtly sphere young people on the one hand learned by personal communication with their teachers and on the other hand by borrowing from famous models present in collective memory and relayed both in writing and by oral tradition. ${ }^{59}$ Either way, the issue is the personal, performative, experience-oriented and affective imparting of knowledge.

Thus when people with feudal or courtly backgrounds entered the monastery in the prime of their lives, to many of them the forms and techniques of teaching and learning were not all that unfamiliar. ${ }^{60}$ For quite similarily to the admonishment of young noblemen to emulate the heroes from courtly epics, the monastic 'theorist' Hugh of St Victor describes monastic learning as imitatio on the basis of legends of the saints. The 'progress' from exempla through imitatio to appropriation is augmented in liturgic practice by the progress from lectio through contemplatio or meditatio to spiritually incorporated' experiential knowledge. The obcainment of divine wisdom (sapientia) is practice-oriented. It is appropriated by way of experientia. ${ }^{61}$ In both cultural environments of courtly and monastic learning, not single items of knowledge are learned, but a whole way of life.

To come to a preliminary conclusion, at least two points seem obvious to me: First, contemporary concepts of sensuality and emotions are manifold and char. acterized by numerous transitions between materiality and spirituality; between body, spirit and soul, physical and spiritual love, this world and the afterlife and the different modes of living in and between these worlds. Pictorial and narrative representations of dialogues between the 'persons' involved, emphasizing the 'reality' of the deceased, of saints and sometimes demons and the devil, as well as prayers like the one I quoted at the outset, mixing religious topoi and personal motives, all illustrate the importance of embodying elusive matters of faith by making them sensually and emotionally reproducible and tangible. Tak- ing historical contexts and the dynamics of emotional articulations seriously we encounter a whole range of representations of emotions in the past that cannot be reduced to simple patterns. Source material of the kind presented here indeed reveals a complex picture of contemporaries' affective lives that often seems at odds with medieval religious norms or at least full of contradictions. It thus seems important to draw attention specifically to these contradictions, as they help us uncover the heterogenous and often nonlinear processes in which "emotions' are constructed, as they are by no means self-evident, let alone universal, but complex effects of processes of naturalization. ${ }^{62}$

Second, a vital characteristic of the reform movements of the eleventh and twelfth centuries was that their pursuit of the beata vita was transtormed into a comprehensive claim to societal renewal. Stefan Weinfurter has recently called this the 'functionalization of the good' in the service of politics which in turn became moralized in the sense of reform. ${ }^{63}$

To more fully understand the processes at work here, the concepts of 'emotional communities' and 'emotional repertoires' could be important tools, as we have to analyse more thoroughly the intersections of communities of different sorts and their members' motives and intentions within their political and religious contexts of monastic and secular discourses and spaces, if only because the persons involved were mostly members of an elite that moved between them. Within these networks of social relations different modes of identification played a role: Social status (ordo), both in the sense of birth, ancestry and social origin and in the sense of belonging to a religious order; political alliances and relations between political, clerical and intellectual elites; and not least the social categories of age and gender. ${ }^{64}$ Thus, looking for similarities in the representations - words, images and performances of emotions - that make up 'emotional repertoires' and provide people with options for their actions, and for their moral/political functions that might have built emotional communities across functional borders is as promising as asking if this was in fact particular to the eleventh and the twelfth centuries. The example of the Dialogus miraculorum rather suggests that the phenomenon of overlapping social, cultural and emotional communities was ever growing from the beginning of thirteenth century on, especially in relation to popular preaching and to the increasing use of the vernacular in the context of the growth of urban culture. 
24. The Persian/Ottoman term for the 'cocked cap' is 'kej-küläh', for which see, for example, A. Schimmel. As Through a Yeil: Mystical Poetry in Islam (New York: Columbia Universiry Press, 1982), pp. 67-8 and n. 69.

25. Akyüz (ed.), Fuzüli Divanu, p. 46 and (Ottoman Script) p. 16. Tarlan (ed.), Fuzüli, p. 23.

26. The 18,000 worlds created by God are made up of Allah's active and passive manifestations (akl-i küll, nefs-i küll), nine heavens, four elements, three natural kingdoms (animal, vegetable, mineral) times the 'infinite' number 1,000. For a complete explication of this poem (in Turkish), sec A. A. Şentürk, Osmanli Siriri Antolojist (Istanbul: Yapı Kredi Yayınları, 1990), pp. 236-8.

27. M. Çavuşoğhu and M. A. Tanyeri (eds), Zatĭ Divanz III (Istanbul: Istanbul Universitesi Edebiyat Fakültesi Yayınları, 1987), p. 3.

28. The most striking image of this relation between the party and dervish practices is in a miniature for which I was unable to obtain permission, probably added in the nineteenth century to the British Library manuscript of Kâsim. Envar's, Divan (OR 11363. t. 148a).

29. A. N. Tarlan (ed.), Hayälì Bey Divant (Istanbul: Bürhaneddin Erenler Matbaası, 1945), p. 111.

30. For Izzet Molla's poem see Andrews, Black and Kalpakh, Ottoman Lyric Poetry, p. 157 (bio. 263-4).

3 Lutter, 'Preachers, Saints, and Sinners: Emotional Repertoires in High Medieval Religious Role Models'

1. Prayer book, Nonnberg (Clm. 14848, St. Emmeram), ff. 4-6: 'O domine de virgine natus, ... O domine arridens matri, per risum illum concede mihi, obsecro, congaudere tuae perpetuae iocunditati.... O domine sugens ubera matris... O domine recumbens in sinu matris ... $\mathrm{O}$ domine vix valens loqui lingua balbuciente ... $\mathrm{O}$ domine cursitans circa matrem more parvulorum, ... O domine deosculans dulcia labia matris genitricis ... O domine circumcingens colla matris dilecte...

2. Preliminary versions of this paper were presented at the international workshop Encoding/Decoding of Emotions - Medieval to Early Modern', Vienna, Austria (2005), and at the international conference 'Cultural History of Emotions in Premodernity', Umea, Sweden (2008). It draws on material and arguments also used in C. Lutter, 'Geschlechr, Gefühl, Körper - Kategorien einer kulturwissenschaftlichen Mediävistik?', L 'Homme. Europäische Zeitschrift fur feministische Geschichtsurissenschaff, 18:2 (2007), pp. 9-26, and C. Lutter, "Wunderbare Geschichten" Frömmigkeitsvorstellungen und -praxis in miracula des 12. Jahrhunderts, in J. Rogge (ed.), Religiöse Ordnungsvorstellungen und Frömmigkeitspraxis im Hoch-und Spatmittelalter (Mainz: Didymos 2008), pp. 41-61. I am grateful to Karl Brunner, Albrecht Diem, Max Diesenberger. Stefan Erdei, Andrea Griesebner, Daniela Hammer-Tugendhat, Piroska Nagy, Barbara Rosenwein and Horst Wenzel for discussion and comments, as well as for help with the translation.

3. For a thorough discussion of historiography and modern scholarship of 'emotions' see B. H. Rosenwein, 'Worrying about Emotions in History', American Historical Review, 6 (2002), pp. 821-45, and B. Rosenwein, Emotional Communities in the Early Middle Ages Ithaca, NY: Cornell University Press, 2006). On the medicyalist debate in the Germanspeaking world cf. esp. C. S. Jaeger and I. Kasten (eds). Codierungen von Emotionen im Mittelalter. Emotions and Sensibilities in the Middle Ages (Berlin: de Gruyter, 2003); and R. Schnell, 'Historische Emotionsforschung, Eine mediävistische Standortbestimmung,
Frïbmittelalterliche Studien, 38 (2004), pp. 173-276; for a comparative discussion most recently: D. Boquet and P. Nagy (eds), Le sujet des emotions au Moyen discussion Beauchesne, 2009) and Politiques des emotions at Moyen Ase (Taven Age (Pari Edizioni del Galluzzo, 2011)

4. E.g. Rosenwein, Emotional Communities, pp. 3-5, and Nagy and Boquet (eds), sujet des emotions, $15-51$, 'emotions'/'Emotionen' -51 , on modern languages. Both in English and in German demically to the rentan' seem to have become the most general terms for referring acalanguages they are ated phenomena and their articulations. At the same time in both pragmatic use of the term 'emotinderstood colloquially, a convergence that allows for a pragmatic use of the term 'emotions' as a first approach to this fuzzy category: I borrow the phrase 'fuzzy category' from B. Rosenwein, 'Emotions and Material Culture: A "Site under Construction", in G. Jaritz (ed.), Emotions and Material Culture (Vienna. Verla der Österreichischen Akademie der Wissenschaften, 2003), pp, 165-72, pienna: Verlas

5. See Rosenwein Emotionat Comisenschaften, 2003), pp. 165-72, p. 168.

Table 2 at p. 40 for Ciccro's list, with furcher liter pp. 32-56, on the ancient legacy. esp. of Mind: From Stoic Agitation, whe Christian Temature. Cf. R. Sorabji, Emotion ind Peace

6. The first quote is from ed. R. Willems, CCSL 36 . Tustinc, In Iohannis evangelium tractatus CXXIV, tract. 46.8, ed. R. Willems, CCSL 36, Turnhout: Brepols 1954, p. 403, the second one from Augustine, De Civitate Dei 9.4, ed. Bernard Dombart u. Alfons Kalb, CCSL 47, Turnhout: Brcpols 1955, p. 251, quoted and translated in Rosenwein, Emotional Communities, 48. For a comprehensive study of affectus/affection see D. Boquet, $L$ 'ordre del affect au Moyen Age. Autour de l'anthropologie affective d'Aelred de Rievaulx (Caen: Publications du CRAHM, 2005).

7. Rosenwein, Emotional Communities, p. 27

Press, 1988); for an History between Practices and Representations (Cambridge: Polity Spiegelungen. Zur Kuturdisciplinary perspective on medieval literature see H. Wenzed, 2009), esp. pp. 97-8.

9. $\mathrm{My}$

My notion of the construction of experience follows J. Scott, "The Evidence of ExperiMarvels: The Limits Mittelst The Limits of Alterity', in F. J. Felten and N. Jaspert (eds), Vita Religiosa im medieval (Berlin: Duncker \& Humblot, 1999), pp. 799-817, esp. p. 811, in relation to medieval writers and their sense of the cultural construction of experience and personal perspective. Cf. also Lutter, Geschlecht, Gefübl, Körper. 10. R. Newhauser, The Treatise on Vices and Virtues in Latin and the Vernacular (Turnhout:
Brepols, 1993). On ancient and early Christian taditions of enalo their partial identification with vices with respect to sins ans of evaluation of emotions, of these notions, see Sorabji, Emotion and Pect to sins and the gradual differentiation Communities,

1. Prudentius, Clemens Aurelius, Psychomachia. Die Psychomachie des Prudentius, ed. and
trans. U. Engelmann (Vienna: Herder 1959). a: Herder 1959)

(Turnhing Ordo virtutum, in Opera minowa, ed. P. Dronke, CCCM 226 (1urnhout; Brepols, 2007), pp. 481-521; Herrad of Hohenburg, Hortus deliciarum, ed. R. Green, M. Evans, C. Bischoff and M. Curschmann, 2 vols (Leiden; Brill, 1979), Twelfih Century (Ph. The Garden of Delights. Reform and Renaissance for Women in the Twelfith Century (Philadelphia, PA: University of Pennsylvania Press, 2007) 
13. For the former argument see most recently her contributions 'Problems and Methods in the History of Emotions', Passions in Context. Journal of the History and Philosophy of the Emotions, 1 (2010), pp. 1-32, esp. pp. 12-21, and to this volume, for the latter Rosenwein, Enotional Communities, esp. p. 25, and Walter Andrews' contribution to this volume, esp. pp. 21-3. On medicval audiences see e.g. C. Muessig, Preacher, Sermon, and Audience in the Middle Ages (Leiden: Brill 2002)

14. From the vast bibliography on these related ropics see G. Melville and M. Schürer (eds). Das Eigene und das Ganze. Zum Individuellen im mittelalterlichen Religiosentum (Münster: LIT, 2002), K. Schreiner (ed.), Frömmigkeit im Mittelalter. Politisch-soziale Kontexte, visuelle Praxis, körperliche Ausdrucksformen (Munich: Fink, 2002), and A. Beach (ed.), Manuscripts and Monastic Culture. Reform and Renewal in Twelfth-Century Germany (Turnhout: Brepols, 2007).

15. On the cultural construction of emotions in religious communities see also Paola Baseotto's contribution to this volume. For a comparable methodological approach see also Kristine Steenbergh's contribution to this volume. I use the notion of "emotional repertoires' according to Gadi Algazi's idea of 'cultural repertoires': G. Algazi, 'Kulturkult und die Rekonstruktion von Handlungsrepertoires', L'Homme. Zeitschrift für feministische Gescbichtswissenschaft, 11:1 (2000), pp. 105-19, esp. pp. 111-13. This notion can be related to William Reddy's concept of 'emotives', see e.g. his definition 'emotion talk and emotional gestures' which 'alter the states of the speakers from whom they derive', in W. Reddy, The Nituigation of Feeling. A Framework for the History of Emotions (Cambridge: University Press 2001), here at p. 327, discussed in Rosenwein, Emotional Communities, pp. 18-25, here at p. 18. Rosenwein stresses the analogy of Reddy's notion of 'emotives' to 'performatives', thus their transformative ability.

16. Caesarius of Heisterbach, Dialogus miraculorum / Dialog über die Wunder, ed. and trans. N. Nösges and H. Schneider, Fontes Christiani 86/1-5, 5 vols (Turnhout: Brepols, 2009), quotes: vol. 1, pp. 5,7, vol. 3, pp. 984, 8, 1, vol. 4, p. 1506.

17. Dialogus miraculorum, prologue, vol. 1, quotes at pp. 200 and 202.

18. H. Penz, "Colligite fragmenta ne pereant": Funktionen von Mirakeln am Beispiel des Dialogus miraculorum von Caesarius von Heisterbach (1180-1240)' (MA thesis, Vienna University, 1994). pp. 37-47, quote at p. 56. On the importance of the dialogical genre in the twelfth century see S. Flanagan, 'The Speculum virginum and Traditions of Medieval Dialogue', in C. J.Mews (ed.), Listen, Daughter. The Speculum Virginum and the Formation of Religious Women in the Middle Ages (New York: Palgrave, 2001), pp. 159-79. For more details on this argument see below pp. 58-60.

19. Dialogus miraculorum, prologuc, vol. 1, pp. 202; cf. B. P. McGuire, 'Friends and Tales in the Cloister. Oral Sources in Caesarius of Heisterbach's Dialogus Miraculorum', Analecta Cisterciensia, 36 (1980),pp. 167-245, and B. P. McGuire, 'The Cistercians and the Rise of the Exemplum in Early Thirteen Century France. A Reevaluation of Paris BN MS lat. 15912: Classica et Mediavalia, 34 (1983), pp. 211-67.

20. On the relations between the Dialogus monachorum and Caesarius' sermons $f f$. A. E. Schönbach, 'Caesarius von Heisterbach I, II und III, Studien zur Erzählliteratur des Mittelalters, Teil 4, 6 und 7', Sitzungsberichte der philosophisch-bistorischen Classe der kisiserlichen Akademie der Wissenschaften, 144 (1902), pp. 1-93, 156 (1908), pp. 1-51 and 163 (1909), pp. 1-90, here III, pp. 5-29; of. also Penz, 'Colligite fragmenta, p. 56f; on Cistercian miracle collections that served as source material for the Dialogus miraculorum see B. P. McGuire, 'Written Sources and Cistercian Inspiration in Caesarius of Hcisterbach: Analecta Cisterciensia, 35 (1979), pp. 227-82; for a comparative approach cf. F. C. Tubach, Index Exemplorum. A Handbook of Medicval Religious Tales (Helsinki Suomalainen Tiedeakat 1969),

21. E.g. Dialogus minuculorum, 4, 12, vol. 2, p. 702: Missus est iuvenis, sanguine nobilis, tanquam qui apud Regem propter cognatos aliquid amplius posset impetrare quam ceteri, Dialogus miraculorum, vol. 2, pp. 12, 40, vol. 5, p. 2278: Ego eundem Abbatem Coloniae vidi, eratque homo valde saecularis, magis se conformans militi quam monacho.

22. E.g. Heisterbach, Dialogus miraculorum 4, 36, vol. 2, pp. 760-2 (Artus); ibid. 4, 12 and 13, vol. 2, pp. 702-5 (shoes); 4,14 , vol. 2, pp. 704-7 (horse); 4, 48, vol. 2, pp. 786-9 (lice).

23. On definitions and uses of exempla: C. Bremond, J. LeGoff et J.-C. Schmitt, L' Exemplum. Typologie des sources du moyen àge occidental 40,2. ed. augm. (Turnhour Brepols, 1996).

24. CE. McGuire, 'Friends and Tales in the Cloister'.

25. On Caesarius and his working method see also Penz, 'Colligite fragmenta', p. 46, and recently U. Kleine, Gesta, Fama, Scripta. Rheinische Mirakel des Hochmittelalters zwischen Geschichtsdeutung, Erzählung und sozialer Praxis (Stuttgart: Steiner, 2007).

26. Recent work on such collections is provided by D. Aigle (ed.). Miracle et Karama Hagiographies médievales comparées (Turnhout: Brepols, 2000); M. Heinzelmann et al (eds), Mirakel im Mittelalter. Konzeptionen - Erscheinungsformen - Deutungen (Stuttgart: Steiner, 2002); K. Herbers (ed.), Mirakelberichte des frühen und bohen Mittelalter (Darmstadt: Wissenschaftliche Buchgesellschaft, 2005).

27. The quote is from Codex Admontensis (hereafter Cod. Admont.), 638, ff. $83 \mathrm{v}-85 \mathrm{v}$ : De muliere apostatante, hier f. 84v. Seminal is B. Ward, Miracles and the Medieval Mind. Theory, Reiord, and Event 1000-1215 (Philadelphia, PA: University of Pennsylvania Press, 1982); on medieval categories and definitions of miracles and wonders see C. W. Bynum, 'Wonder', American Historical Review, 102:1 (1997), pp. 1-26, and C. W Bynum, 'Miracles and Marvels'; recently M. E. Goodich, Lives and Miracles of the Saints (Aldershor: Ashgate, 2004), and G. Signori, Wunder. Eine historische Einfuibrung (Frankfurt/Main: Campus, 2007).

28. A good overview is provided in the introduction to Herbers et al. (eds). Mirakelberichte, pp. $1-28$.

29. For an overview of Marian miracle collections of the time, see A. Mussafia, 'Studien zu den mittelalterlichen Marienlegenden I', Sitzungsberichte der philosophisch-historischen Classe der kaiserlichen Akademie der Wissenschafien, 113 (1886), pp. 917-94, here at pp. 921-36. See also the summary by H. Hilg, 'Marienmirakelsammlungen', in K. Ruh (ed.), Die deutsche Literatur des Mittelalters. Verfasserlexikon, vol. 6 (1987), pp. 19-42. Seminal on Marian piety is K. Schreiner, 'Marienverehrung, Lesekultur, Schriftlichkeit. Bildungs- und frömmigkeitsgeschichtliche Studien zur Auslegung und Darstellung von Mariä Verkündigung', Frühmittelalterliche Studien, 24 (1990), pp. 314-68; K. Schreiner, Maria. Jungfrau, Mutter, Herrscherin (Munich, Vienna: Hanser, 1994), and G. Signori, Maria zwischen Katbedrale, Kloster und Welt (Sigmaringen: Thorbecke, 1995). On the history of Admont with detailed further references cf. C. Lutter, Geschlecht \& Wissen, Norm \& Praxis, Lesen \& Schreiben. Monastische Reformgemeinschaften im 12. Jahrhundert (Vienna: Oldenbourg, 2005), pp. 52-69.

30. On the nuns' participation in contemporary manuscript production in Admont and other monasteries in South Germany see A. Beach, Women as Scribes: Book Production and Monastic Reform in 12th-Century Bavaria (Cambridge: University Press, 2004) and A. Beach (ed.), Manuscripts and Monastic Culture. On the spiritual exchange between 
Admont 's sanctimoniales and their pastors and advisors and the women's respective intellecrual competences see Lutter, Geschlecht \& Wissen.

31. From the enormous bibliography sec the following key readings: G. Constable, The Reformation of the Twelfth Century (Cambridge: University Press, 1996); S. Weinfurter, Die Macht der Reformidee. Thre Wirkkraft in Ritualen, Politik und Moral der spätsalischen Zeit, in J. Rogge (ed.), Religiöse Ordnungsvorstellungen und Frömmigkeitspraxis im (Mainz: Didymos 2008), pp. 13-39. On the concepts of vitu Hoch- tund Spatmittelalter (Mainz: Didymos 2008), pp. 13-39. On the con (ed.), Manuscripts and Monastic Culture.

32. The most important orientation remains Jakob Wichner's handwritten catalogue from 1887/8. On Admont's illuminated manuscripts most recently S. Secberg, 'Illustrations 1887/8. On Admont's illuminated manuscripts most recently S. Secberg, 'llustrations in the Manuscripts of the Admont Nuns from the Second Half of the Tweltth Century. Reflections on Their Function, in Beach (ed.), Mants 99-121. On the exercise of a monastic way or life, sec U Kusterf De im 12 Jahrhunder ten. Volkssprachliche Hoheliedausleging und monastische Lebensform im 12. Jabrhunden (Düsseldorf: Droste 1985), and the respective chapter in Lutter, Geschlecht of Wissen. pp. 119-25.

33. Mussafia, 'Marienlegenden', pp. 936-7, on the tradition of a collection edited by Bernhard Pez according to a manuscript from the Cistercian monastery Heiligenkreuz in Lower Austria (thirteenth century); ibid., pp. 937-44, short synopses of the forty-two mime As a discussion of the variations between the Codex Admont 638 and other known manuscripts, p. 947-8.

Cod Admont. 638, ff. 69r-82r: De Theophylo vicediacono; ibid., ff. 82r-83v: De moniale stulta: ibid, ff. 83v-85v: De muliere apostatante; ibid, ff. 85v-87v: De clerico et monithe mis manuscript (the miracle discussed here titled ale lascivis. Two of the miracula from this mallection's 'ordinary repertoire', ibid., ff. De moniale lubrica, which still belongs to the collection's ordinary repertoire, ibid., If66v-68r, and De moniale stulta) are published in Lutter, Geschlecht é Wissen, pp. 235-7.

35. For Caesarius of Heisterbach see the introduction to the most recent edition: Dialogus miraculorum, vol.1. pp. 9-103, esp. 55-83, and the overview provided by Penz, Colligite fragmenta', pp. 46-51 and 55-8.

36. Luter, Geschlecht of Wissen, p. 235: Fuit quedam sanctimonialis in quodam conventu feminarum summo domino famulantium, que pre cunctis sororibus amabatur ab omnibus. Hee namque plus aliis ieiuniis studebat vigiliis ac gemitibus et aliis virtutibus quam per plurimis quibus placens alcissimo et cius genitrici. Manebat in cenobio tali degens obsequio, sed, ut vidit diabolus, qui semper est invidus, quod ab ea sic repulsus esset nec non despectus, suasit illi misere, domini precepta spernere, virginitatem, quam in mente et in corpore servabar, perdere.

37. Ibid.: Postquam autem cecidit, ingemuit amare atque scelum perhorruit, quod fecerat, peniruit, quia dominum et eius piissimam genitricem offensos habuit. Mox vero ad pedes penittit, quidis dis penis, an adhuc abbatisse cecidit quam, ut vidit non cxpavit, sed confestim in la eit in penis, an adhac esset an ex illis vel si sua delicta illi essent condonata. Ad hec illa ei narrat, que perpessa esset mala et que ad huc eam digne oporteret sustinere: Sum in penis, inquit, mater, et eror vehementer, et heu mihi misere nec commissa mea adhuc mihi sunt dimissa. Sum anim inter feminas deputata laicas perdidique stolam primam virginalem, quam habebam, quando virgo casta ac domino dicata eram.

38. Ibid. Quam ego recognoscens esse clementissimam Mariam exclamavi flens ac dicen bide Ubi eras gloriosa, quando huc intravi? O domina, si clamantem audisti, cur vocem spre- visti? Nonne vides ígnes, qui me urunt infernales, Alamme quippe me incendunt, nec omnino me consumunt? O domina Maria, mater Christi, iam succurre festinanter et in his doloribus non sinas diutius me esse, sed exaudi me clementet, quam te amavi et imploravi frequenter. Poteris ne oblivisci, quotiens te salutavi et quod tibi commendabam me semper et omnes, quos recipit ecclesia catholica! Heu mihi, nunc apparet quam [!] in vanum laboravi!

39. Ibid.: ... Nam peccasti quam plurimum relinquens meum filium, cui virgo desponsata eras atque consecrata te ipsam tradens diabolo et me quoque ad maximam iracundian commovisti. Nam qui spernit meum natum, exhonorat me nimium. Sed quia me cottidie salutabas, dulcissime serviebas, honorabas, extollebas et amabas, me orabas pro te et omnibus christianis fidelibus, sic secura quod non peribis in eternum, sed salvaberis.

40. On functions of emotions $\mathrm{cf}$. Steenbergh in this volume, esp. in her conclusion at p, 133 The example De moniale stulta (cf. n. 34, abovc) also gives comprehensive details on the forms of a young nun's compunction (compunctio) that finally leads to her salvation after a lengthy argument between the Virgin Mary and some demons. Cf. P. Nagy, Le don des larmes an Moyen Age (Paris: Albin Michel, 2000); cf. also G. Althoff, 'Empörung, Tränen, Zerknirschung. "Emotionen" in der öffentlichen Kommunikation des Mitrelalters', Frühmittelalterliche Studien, 30 (1996), pp. 60-79, though here the focus is morc on the symbolic acts of communication in circumstances of political conflicts, yet still remains within the same Christian-motivated discursive frame of reference.

41. Dialogus miraculorum, 2 (distinctio secunda de contritione), vol. 1, pp. 342-497, gives several definitions in 2, 1, pp. 342-9, e.g. on the location of contrition, at p. 348: Interior est in amaritudine cordis; exterior in afflictione corporis, followed by thirty-five examples.

42. Hilg, 'Marienmirakelsammlungen', p. 20; on liturgy and spiritual office in relation to the Hirsau Liber Ordinarius; Seeberg, Illustrations, on Admont's Matutinale; cf. Benedicti Regula, ed. R. Hanslik, CSEL 75 (Vienna: Verlag der Osterreichischen Akademie der Wissenschaften, 1960, repr. 1977), pp. 8-20. On Caesarius cf, n. 20 above.

43. For further examples for anger as a positively connotated passio see $\mathrm{K}$. Brunner, 'Zorn und andere Missverständnisse', in Jaritz (ed.) Emotions and Material Culture, pp. 7-15. here at pp. 9-10; on the range of meanings of anger cf. the essays in B. Rosenwein, Anger's Past: The Social Uses of an Emotion in the Middle Ages (Ithaca, NY: University Press 1998).

44. Speculum virginum, ed. and trans. J. Seyfarth, Fontes Christiani 30, 4 vols (Freiburg/ Breisgau, Vienna: Herder, 2001): discussed in Mews (ed.), Listen Daughter with a focus on gender roles and representations, esp. Flanagan, 'Traditions of Medieval Dialogue', and M. Powell, 'The Speculum virginum and the Audio-Visual Poetics of Women's Religious Instruction', pp. 111-35.

45. Comprehensive discussion in B. Jussen, Der Name der Witwe: Erkundungen zur Semantik der mittelalterlichen Bußkultur (Göttingen: Vandenhoeck \& Ruprecht, 2000).

46. Das St. Trudperter Hobelied. Eine Lehre der liebenden Gotteserkenntnis, ed. and trans. F. Ohly (Frankfurt/Main: Dt. Klassiker Verlag, 1998), with an extensive commentary on the exegetical tradition of the Song of Songs and its historical contexts summarizing decades of study by the editor on these issues. For the quote see ibid., 145.9-10, and 12-13: An diseme broche suln die briute des almehtigen gotes ir spiegel haben; on this topic also K. Brunner. "Quae est ista, quae ascendit per desertum". Aspekte des Selbsrverständnisses geistlicher Frauen im 12. Jahrhunderr', Mitteilungen des Instituts für Österreichische Geschichtsforschung, 107 (1999), pp. 271-310. 
47. Generally A. Astell, The Song of Songs in the Middle Ages (Ithaca, NY: Cornell Univ. Press, 1995): on the model of the brides of Christ ef. the seminal survey by Küsters, Der Press, 1995): Gissen, pp. 143-66, with verschlossene Girten, and more recently Lutter, Geschlecht W Wissen, PP. 143-66, with
further references.

48. Cod. Admont.. ff. 82r-83v: De moniale stulta features red highlights for the change of speakers, On the monastic lectio cf. Küsters, Der verschlossene Garten, pp. 24-39; on performative staging of emotions cf. Steenbergh, pp. 121-3.

49. Ordo virtutum ed. Dronke, on religious drama see recently e.g. I. Kasten and E. Fischer-Lichte (eds), Transformationen des Religiösen. Performativitat und Textualität im cher-Lich (erlin: de Gruyter, 2007): N. Largier, 'Scripture, Vision, Performance: geistlichen Spiel (Berlin: de Griyter, 2007), N. Latgier, Scripley, Vision, Performance: Visionary Texts and Medieval Religious Drama, in: K. Starkey and H. Wenzel (eds),
Vistal Culture and the German Middle Ages (New York: Palgrave Macmillan, 2005).

50. Ordo virtutum, ed. Dronke, Introduction p. 488; On gender roles in the imagery of the militio Christi sec Lutter. Geschlecht of Wissen. pp. 126-31, and Lutter, Zwischen Hof und Kloster. Kulturelle Gemeinscbaften im mitrelalterlichen Österreich (Vienna: Böhlau, 2010), pp. 11-14 and 40-8.

51. Quoted and discussed in C. J. Mews, 'Hildegard of Bingen, the Speculum virginum and Religious Reform', in A. Haverkamp (ed.), Hildegard von Bingen in ihrem historischen Unfeld (Mainz: Philipp von Zabern, 2000), pp. 237-67.

52. Cod Admont 18, the embrace at f. 164v; Mary s representation as queenly maiden at $f$ 163r. Cf. Seeberg, 'Lllustrations', pp. 113-7, and Lutter, Geschlecht \&' Wissen, pp. 155-9. 163r. Cf. Seeberg, 'Llustrations, pp. 113-7, and Lutter, Gescinlecht of 53. Rosenwein, Emotional Communities, e.g. p. 2: '... groups in which people adhere to the same norms of emotional expression and value - or devalue - the same or related emotions. More than one emotional community may exist - indeed normally does exist cions. More than only, and these communities may change over time'. She pits this term - contemporaneously, and these communities may change over time. She pits this 'emowhich allows to conceive of various coexisting overlapping, but also conflicting 'emotional communities' against William Reddy's notion of 'emotional regimes' as dominant also $p, 25$ for an emphasis on the 'social and relational nature of emotions'.

54. Cod Admont. 638. ff. 83v-85v: De muliere apostatante. On the following argument with further source material from Admont see Lutter, Geschlecht \& Wissen, part IV, pp 178-220, and Lutrer, Zwischen Hof tund Kloster, pp, 103-15.

55. The collection is partly edited and discussed by A. Beach, "Voices from a Distant Land: Fragments of a Twelfth Century Nun's Letter Collection', Speculum, 77 (2002), pp. $34-54$.

56. I. M. Ferrante, "Licet longinquis regionibus corpore separati". Letters as a link in and to the Middle Ages', Speculum, 76 (2001), pp. 877-95. See also the contributions of Karl Brunner and Eva Cescutti in C. Lutter (ed), Funktionsrätume 'Wabrnehmungsräume' Gefüblsriume. Mittelalterliche Lebensformen zwischen Hof und Kloster (Vienna: Böhlau, 2011).

57. Cod. Admont. 638, ff. 83v-85v; De muliere apostatante, and ff. 46v-50r: De abbatissa auzedam impraegnata, and Anndes Admuntenses, ed. W. Wattenbach, MGH SS 9, 1851 quated m im (repr. 1925), pp. 569-79, at p. 578-9. This, of course,

58. Esp in his Book IV on temptation, comprising 103 chapters, vol. 2, pp. 666-947. On the Esp.in their consequences for the issue of the audiences of the texts discussed see pp. 52-3, above.
59. On the courtly environment Horst Wenzel's work is seminal; see most recently Wenzel, Spiegelungen, with comprehensive source material, and also C. Lutter, 'Affektives Lernen im monastischen und höfischen Gebrauch von exempla', in Lutter, Funktionsräume, pp. $121-43$.

60. With a stress on gender and generation see e.g. A. B. Mulder-Bakker, 'The Metamorphosis of Woman: Transmisssion of Knowledge and the Problems of Gender', in P. Stafford and A. B. Mulder-Bakker (eds), Gendering the Middle Ages, Gender \& History, 12:3 (2001), pp. 112-34, esp. p. 118.

61. On Hugh of St Victor's De tribus maximis circumstantiis gestorum, ed. W. M. Green Speculum, 18:4 (1943), p. 484-93, see the English translation (Appendix A, pp. 339-44 and discussion in M. Carruthers, The Book of Memory. A Study of Memory in Medieval Culture (Cambridge: University Press. 1990, 2nd ed 2008), here at p. 302-3.

62. On the relation between Christian materiality and spirituality C. W. Bynum's work is seminal, cf. most recently: C. W. Bynum, Christian Materiality. An Essay on Religion in Late Medieval Europe (New York: Zone Books, 2011). For a more comprehensive development of the argument made here see also Lutter, 'Geschlecht, Gefühl, Körper'.

63. Weinfurter, 'Die Macht der Reformidee', pp. 14-22.

64. On this issue of. Lutter, Zwischen Hof und Kloster and Funktionsräume.

4 Baseotto, 'Theology and Interiority: Emotion as Evidence of the Working of Grace in Elizabethan and Stuart Conversion Narratives'

1. My use of the terms 'puritan' and 'puritanism' in their broader meanings is discussed below.

2. I use the term 'emotionology' coined by Peter and Carol Stearns to describe the 'attitudes or standards that a society, or a definable group within a society, maintains toward basic emotions and their appropriate expression,'P. N. Stearns with C. Z. Stearns, 'Emotiono L ogy: Clarifying the History of Emotions and Emotional Standards', AHR, 90 (1985), pp. $813-36$, p. 813

3. B. H. Rosenwein, Emotional Communities in the Early Middle Ages (Ithaca, NY and London: Cornell University Press, 2006), p. 2. My notion of 'emotional communities' follows Rosenwein's definition in Emotional Communities, p. 2: 'groups in which people adhere to the same norms of emotional expression and value - or devalue - the same or related emotions'.

4. P. Collinson, The Elizabethan Puritan Movement (Oxford: Clarendon Press, 1967), p. 12

5. In her contribution to the present volume, Lutter remarks that many members of monastic communities had quite a worldly background and thus moved between monastic and secular communities (see p. 63). Commenting on my article in a personal communication, Lutter observed that the 'cultural walls' erected by the puritans seem to have been even stronger than the material walls of medieval monasticism which 'provides an excellent case for the power of spiritual discourse'.

6. Collinson, The Elizabethan Puritan Movement, p, 27. 'The term "puritan" is used to refer to a broader span of opinion, encompassing those advanced protestants who regarded themselves as "the godly", a minority of genuinely true believers in an otherwise lukewarm or corrupt mass, P. Lake, Anglicans and Puritans? Presbyterianism and English Conformist Thought from Whitgift to Hooker (London: Unwin Hyman, 1988), p. 7.

7. Collinson, The Elizabethan Puritan Movement, p. 26. 